\title{
Record based analysis of indications and complications of 500 cases of lower segment cesarean sections at a tertiary care hospital
}

\author{
Vaishali Chaurasia, Sushruta Shrivastava*
}

Department of Obstetrics and Gynecology, Sultania Zanana Hospital, GMC, Bhopal, Madhya Pradesh, India

Received: 14 December 2018

Accepted: 25 December 2018

\section{*Correspondence:}

Dr. Sushruta Shrivastava,

E-mail: vikrantsush18@gmail.com

Copyright: (C) the author(s), publisher and licensee Medip Academy. This is an open-access article distributed under the terms of the Creative Commons Attribution Non-Commercial License, which permits unrestricted non-commercial use, distribution, and reproduction in any medium, provided the original work is properly cited.

\begin{abstract}
Background: The drastically increasing rate of caesarean section is a topic of constant worry and analysis throughout the world. In order to understand the degree to which caesarean section may be preventable, it is important to know why caesarean section are performed. This study is aimed to find out the rate of caesarean section at our institute, various indications of the procedure and complications related to them.

Methods: This study was carried out retrospectively in the department of obstetrics and gynecology at Chirayu Medical College and Hospital, Bhopal. Study period was from January 2017 to December 2017. 500 cases of lower segment cesarean section were studied including both elective and emergency caesarean sections. Statistical analysis of age, parity, period of gestation, indications of LSCS and complications was done.

Results: The rate of caesarean section came out to be $47.7 \%$, which is far above recommended. Majority of patients (81.6\%) were in 21-30 years age group; while the number of primary and repeat caesarean section were comparable (40.8\% and 59.2\% respectively). Commonest indication was previous LSCS (31.6\%) followed by fetal distress $(21.6 \%)$. Surgical site infection was present in $4.6 \%$ cases whereas, post-partum hemorrhage occurred in $5.8 \%$ cases. Three patients underwent obstetric hysterectomy and two cases of maternal mortality were reported among post LSCS patients.

Conclusions: Increasing rates of caesarean section has contributed to maternal morbidity along with financial burden. Individualization of the indication and careful evaluation, following standardized guidelines, practice of evidencedbased obstetrics and audits in the institution, can help us limit rate of caesarean section.
\end{abstract}

Keywords: Caesarean section, Indication of caesarean section, Maternal morbidity

\section{INTRODUCTION}

Caesarean delivery is defined as the birth of a live or dead foetus through incisions in the abdominal wall (laparotomy) and the uterine wall (hysterotomy). Since 1985 the international healthcare community has considered the ideal rate for caesarean section to be between $10-15 \% .{ }^{1}$ Cesarean section is one of the most commonly performed surgeries today with an increasing rate both in developed and developing countries. ${ }^{2,3}$ Increasing rates can be partly explained by improved surgical and anesthetic techniques, advent of electronic fetal monitoring and availability of tertiary care neonatal facilities. As caesarean section rates increased above $10 \%$ and up to $30 \%$, no effect on neonatal or maternal mortality rates was observed.

Moreover, as with any surgery, caesarean sections are associated with short- and long-term risk which can extend many years beyond the current delivery and affect the health of the woman, her child and future pregnancies. ${ }^{4-6}$ Also, potentially medically unjustified 
cesarean sections appear to command a disproportionate share of global economic resources. ${ }^{7}$

The indications of caesarean section vary among institutions as no standard classification system exists for indications of caesarean section. ${ }^{89}$ A major challenge is that definitions are not standardized and indications can be multiple or related..$^{10}$ Among the existing systems used to classify caesarean sections, the 10-group classification (also known as the 'Robson classification') has become widely used in many countries in recent years. ${ }^{9-11}$ The system stratified women according to their obstetric characteristics, thereby allowing a comparison of caesarean section rates with fewer confounding factors.

In order to understand the degree to which caesarean section may be preventable, it is important to know why caesarean section is performed. This study is aimed to find out various indications of the procedure and their contribution to the total caesarean section rate which may help us to reduce the incidence of caesarean section in future.

The aims and objective of this method is to analyze the rate of cesarean section in our institute, to analyze the maternal and fetal indications for caesarean section, to know the intra operative and post-operative complications.

\section{METHODS}

The present study was a retrospective study conducted in the Department of obstetrics and gynecology at Chirayu Medical College and Hospital, Bhopal from $1^{\text {st }}$ February 2018 to $15^{\text {th }}$ April 2018. The case record of patients who had undergone caesarean section in the institute between $1^{\text {st }}$ January 2017 to $31^{\text {st }}$ december 2017 were traced from the medical records department and operation theatre registers, after approval from research committee of the hospital. All cases of caesarean section whether elective or emergency were included in the study. All the relevant information with respect to demographic profile, clinical presentation and indication of caesarean section, intra operative findings and postoperative complications were noted in a preformed proforma and analyzed in detail.

\section{Inclusion criteria}

- All patients undergoing caesarean section whether elective or emergency, during the study period were included in study.

\section{Exclusion criteria}

- Patients, who had undergone caesarean section elsewhere, admitted at Chirayu medical college during postoperative period, were excluded from the study.

\section{RESULTS}

In this study, the rate of caesarean section came out to be $47.7 \%$ whereas $52.3 \%$ patients had delivered vaginally.

Table 1: Distribution of cases according to mode of delivery.

\begin{tabular}{|l|l|l|}
\hline Type of delivery & Number & Percentage \\
\hline Vaginal delivery & 548 & 52.3 \\
\hline Caesarean section & 500 & 47.7 \\
\hline Total delivery & 1048 & 100 \\
\hline
\end{tabular}

In present study, $81.6 \%$ patients were in 21-30 years age group, which is in accordance to the trend of early marriage and child birth in our country. $12.2 \%$ patients were in 31-35 years age group. Patients $>35$ years of age were $3.8 \%$. Only $12(2.8 \%)$ cases were below 20 years of age.

Table 2: Distribution of cases according to age.

\begin{tabular}{|l|l|l|}
\hline Age group & No. of cases & Percentage \\
\hline$<20$ years & 12 & 2.4 \\
\hline 21-25 years & 209 & 41.8 \\
\hline 26-30 years & 199 & 39.8 \\
\hline 31-35years & 61 & 12.2 \\
\hline >35years & 19 & 3.8 \\
\hline
\end{tabular}

In present study $59.2 \%$ patients were multigravida, while $40.8 \%$ patients were primigravida.

\section{Table 3: Distribution of cases according to obstetric} history.

\begin{tabular}{|l|l|l|}
\hline Parity & No. of cases & Percentage \\
\hline Primigravida & 204 & 40.8 \\
\hline Multigravida & 296 & 59.2 \\
\hline Total & 500 & 100 \\
\hline
\end{tabular}

Majority $(76.8 \%)$ of caesarean section were done at term gestation. Twelve percent patients had undergone caesarean section at $<37$ weeks of gestation while $10.8 \%$ cases were post-dated pregnancies.

Table 4: Distribution of cases in relation to period of gestation.

\begin{tabular}{|l|l|l|}
\hline Period of gestation & No. of cases & Percentage \\
\hline Preterm (<37weeks) & 62 & 12.4 \\
\hline Term $(\geq 37$ weeks) & 384 & 76.8 \\
\hline Postdated(>40wks) & 54 & 10.8 \\
\hline
\end{tabular}

In present study, $74.6 \%$ patients had babies with birth weight more than $2.5 \mathrm{~kg}$. Only $4.4 \%$ babies were below $2 \mathrm{~kg}$ of weight whereas, $21 \%$ babies were between 2.1 to $2.5 \mathrm{~kg}$. 
Table 5: Distribution of cases according to birth weight of baby.

\begin{tabular}{|l|l|l|}
\hline Birth weight & No. of cases & Percentage \\
\hline$<2 \mathrm{~kg}$ & 22 & 4.4 \\
\hline $2-2.5 \mathrm{~kg}$ & 105 & 21 \\
\hline $2.6-3 \mathrm{~kg}$ & 225 & 45 \\
\hline$>3 \mathrm{~kg}$ & 148 & 29.6 \\
\hline
\end{tabular}

In present study, most common indication came out to be previous caesarean section (31.6\%), followed by fetal distress $(21.6 \%)$. About twelve percent patients were operated for cephalo pelvic disproportion (CPD) and $10.6 \%$ had non-progress of labour (NPOL). The incidence of failed induction and placenta previa was equal $(2.4 \%)$. Obstructed labour, abruption placentae and high priority fetus were minor indications each accounting for $<1 \%$ cases.

Table 6: Distribution of cases according to indication of cesarean section.

\begin{tabular}{|l|l|l|}
\hline Indication & Number & Percentage \\
\hline $\begin{array}{l}\text { Previous caesarean } \\
\text { section }\end{array}$ & 158 & 31.6 \\
\hline Fetal distress & 108 & 21.6 \\
\hline Non-progress of labour & 53 & 10.6 \\
\hline $\begin{array}{l}\text { Cephalopelvic } \\
\text { disproportion }\end{array}$ & 59 & 11.8 \\
\hline Breech & 41 & 8.2 \\
\hline $\begin{array}{l}\text { Severe oligohydramnios } \\
\text { with IUGR }\end{array}$ & 26 & 5.2 \\
\hline Failed induction & 12 & 2.4 \\
\hline Placenta previa & 12 & 2.4 \\
\hline $\begin{array}{l}\text { Eclampsia /severe pre- } \\
\text { eclampsia }\end{array}$ & 8 & 1.6 \\
\hline Multifetal gestation & 7 & 1.4 \\
\hline Malpresentation & 5 & 1.0 \\
\hline Abruption placentae & 4 & 0.8 \\
\hline High priority fetus & 4 & 0.8 \\
\hline Obstructed labour & 3 & 0.6 \\
\hline
\end{tabular}

In present study, $5.8 \%$ patients had post-partum haemorrhage, $10.2 \%$ patients required blood transfusion and surgical site infection occurred in $4.6 \%$ cases.

Table 7: Distribution of cases according to complications.

\begin{tabular}{|l|l|l|}
\hline Complications & Number & Percentage \\
\hline Blood transfusions & 51 & 10.2 \\
\hline Post-partum hemorrhage & 29 & 5.8 \\
\hline Obstetric hysterectomy & 03 & 0.6 \\
\hline Surgical site infection & 23 & 4.6 \\
\hline Dense adhesions & 05 & 1.0 \\
\hline Maternal mortality & 02 & 0.2 \\
\hline
\end{tabular}

Intra operatively dense adhesions were present in five cases. Three patients underwent obstetric hysterectomy while maternal mortality occurred in two post-operative patients.

\section{DISCUSSION}

Authors observed the rate of caesarean section is $47.7 \%$ in present study which is much above the norms set by WHO. Similarly, higher rates of caesarean section were observed in studies done at tertiary care hospital in jaipur as $31.8 \%$ and $31.46 \% .^{12,13}$ Mittal et al, reported a rising rate of caesarean section from $17.15 \%$ in 2001 to $\geq 28.93 \%$ in $2011 .^{14} \mathrm{~A}$ rate of $54.9 \%$ was reported in mainland China in 2011 by Lieu et al and $21.3 \%$ in UK in $2000 .{ }^{15,16}$ The overall rate is higher in present study as it is done at a tertiary care center where more women with high risk pregnancies are admitted. Also, this institute caters to a large population of referred cases from nearby PHCs and CHCs. It is also possible that caesarean section rates have been overestimated as vaginal deliveries at home are not reported.

The most common indication for caesarean section in present study was previous caesarean section (31.6\%). Anand Nikhil et al,and Pandya $\mathrm{J}$ M et al also reported $42.09 \%$ and $46.2 \%$, respectively as the most common indication for caesarean section. ${ }^{17,18}$ After one LSCS there is $67 \%$ chance of having repeat caesarean delivery. ${ }^{19}$ The low threshold for performing VBAC (vaginal birth after caesarean section ) is probably due to fear of uterine rupture in labour which is 5.2/1000 VBAC compared with (1.6/1000) ERCD (elective repeat caesarian delivery) and it can be catastrophic leading to perinatal death $(1 / 2000)$ and very rarely maternal death. ${ }^{20-}$ 22

On the other hand, the secondary rise in repeat caesarean delivery has been associated with an increase in severe complications particularly the complication of placentation like placenta previa and placenta accreta which in turn increases the maternal morbidity and even mortality. ${ }^{23,24}$

In present study trial of labour after caesarean section was given very judiciously as many patients were not having documentation of previous caesarean records, so were not candidate for VBAC. Authors are working on this group to decrease the rate of repeat caesarean section. In our setup no trial was given to previous two or more scars due to presumed risk of maternal and fetal complications. $^{25}$

Second most common indication for caesarean section was found to be fetal distress $(21.6 \%)$. This could be attributed to very liberal use of CTG and intense fetal monitoring. Similar results were reported by Pandya J M et al, and Liu et al (11.81\%). ${ }^{18,26}$ Non-progress of labour (10.6\%) and CPD (11.8\%) contributed to a major proportion of cases. Authors observed $29.6 \%$ of newborns with birth weight $>3 \mathrm{~kg}$ which is due to better antenatal care and increase in number of mothers with 
GDM with macrosomic babies leading to higher rates of CPD and NPOL. Caesarean section due to breech was $8.2 \%$ and severe oligohydramnios with IUGR was $5.2 \%$. Improved NICU facilities have led to increased number of caesarean sections in preterm, PPROM and IUGR cases. There has been an increase in number of patients with age >35yrs and conceptions after artificial reproductive technique leading to increased apprehension in mothers for the wellbeing of their unborn child which has also contributed to increased rate of caesarean section. Post-partum haemorrhage $(5.8 \%)$ and dense adhesions (1\%) were the common complications during caesarean section. Two patients underwent classical caesarean section followed by obstetric hysterectomy due to placenta previa with increta. One obstetric hysterectomy was done following atonic PPH not controlled by uterotonics and internal iliac artery ligation. Chavda D et al, reported similar complications in their study. Two cases of maternal mortality were reported. ${ }^{27}$

\section{CONCLUSION}

With time, despite increased safety of caesarean section, increasing rates of caesarean section has contributed to maternal and neonatal morbidity along with financial burden. Individualization of the indication and careful evaluation, following standardized guidelines, practice of evidenced-based obstetrics and audits in the institution, can help us limit caesarean section rate.

\section{Funding: No funding sources}

Conflict of interest: None declared

Ethical approval: The study was approved by the Institutional Ethics Committee

\section{REFERENCES}

1. WHO statement on caesarean section rates. Available at: http://www.who.int/reproductivehealth/publications/ maternal_perinatal_health/cs-statement/en/.

2. Vogel JP, Betrán AP, Vindevoghel N, Souza JP, Torloni MR, Zhang J, et al. Use of the Robson classification to assess caesarean section trends in 21 countries: a secondary analysis of two WHO multicountry surveys. Lancet Global Health. 2015;3(5):e260-70.

3. Ye J, Betrán AP, Guerrero Vela M, Souza JP, Zhang J. Searching for the optimal rate of medically necessary cesarean delivery. Birth. 2014;41(3):23744.

4. Lumbiganon P, Laopaiboon M, Gülmezoglu AM, Souza JP, Taneepanichskul S, Ruyan P, et al. Method of delivery and pregnancy outcomes in Asia: the WHO global survey on maternal and perinatal health 2007-08. Lancet. 2010;375(9713):490-9.

5. Villar J, Carroli G, Zavaleta N, Donner A, Wojdyla D, Faundes A, et al. Maternal and neonatal individual risks and benefits associated with caesarean delivery: multicentre prospective study. BMJ. 2007;335(7628):1025.

6. Souza JP, Gülmezoglu AM, Lumbiganon P, Laopaiboon M, Carroli G, Fawole B, et al. Caesarean section without medical indications is associated with an increased risk of adverse short-term maternal outcomes: the 2004-2008 WHO Global Survey on Maternal and Perinatal Health. BMC Med. 2010;8(1):71.

7. Gibbons L, Belizan JM, Lauer JA, Betran AP, Merialdi M, Althabe F. Inequities in the use of cesarean section deliveries in the world. Am J Obstet Gynecol. 2012;206(4):331-e1.

8. Stanton C, Ronsmans C, Baltimore Group on Cesarean. Recommendations for routine reporting on indications for cesarean delivery in developing countries. Birth. 2008;35(3):204-11.

9. Torloni MR, Betran AP, Souza JP, Widmer M, Allen $\mathrm{T}$, Gulmezoglu M, et al. Classifications for cesarean section: a systematic review. PloS One. 2011;6(1):e14566.

10. Singh G, Gupta ED. Rising incidence of caesarean section in rural area in Haryana, India: a retrospective analysis. Int $\mathbf{J}$ Gynecol Obstet. 2013;17(2):1-5.

11. Betran AP, Vindevoghel N, Souza JP, Guelmezoglu AM, Torloni MR. A systematic review of the Robson classification for caesarean section: what works, doesn't work and how to improve it. PloS One. 2014;9(6):e97769.

12. Jawa A, Garg S, Tater A, Sharma U. Indications and rates of lower segment caesarean section at tertiary care hospital-an analytical study. Int $\mathrm{J}$ Reprod Contracept Obstet Gynecol. 2016;5(10):3466-9.

13. Gupta M, Garg V. The rate and indications of caesarean section in a tertiary care hospital at Jaipur, India. Int J Reprod Contracept Obstet Gynecol. 2017;6(5):1786-92.

14. Mittal S, Pardeshi S, Mayadeo N, Mane J. Trends in cesarean delivery: rate and indications. J Obstet Gynecol India. 2014;64(4):251-4.

15. Liu Y, Li G, Chen Y, Wang X, Ruan Y, Zou L, et al. A descriptive analysis of the indications for caesarean section in mainland China. BMC Preg Childbirth. 2014;14(1):410.

16. Treffers PE, Pel M. The rising trend for caesarean birth. BMJ: Brit Med J. 1993;307(6911):1017.

17. Nikhil A. Analysis of Trends in LSCS Rate and Indications of LSCS-A Study in a Medical College Hospital GMERS, Sola, Ahmedabad. Int J Pharm Bio-Scienc. 2015;2(1).

18. Pandya JM, Pandya MJ, Joshi JM, Velani SP. Analytical study of indications of cesarean section. Int J Reprod Contracept Obstet Gynecol. 2017;4(5):1460-3.

19. Thomas J, Paranjothy S. Royal College of Obstetrics and Gynaecology Clinic Effectiveness Support Unit. National Sentinel Caesarean Section Audit Report.

20. Lydon-Rochelle M, Holt VL, Easterling TR, Martin DP. Risk of uterine rupture during labor among 
women with a prior cesarean delivery. New England J Med. 2001;345(1):3-8.

21. Mozurkewich EL, Hutton EK. Elective repeat cesarean delivery versus trial of labor: a metaanalysis of the literature from 1989 to 1999 . Am J Obstet Gynecol. 2000;183(5):1187-97.

22. Rageth JC, Juzi C, Grossenbacher H. Delivery after previous cesarean: a risk evaluation. Obstet Gynecol.1999;93(3):332-7.

23. Nikhil A. Analysis of Trends in LSCS Rate and Indications of LSCS-A Study in a Medical College Hospital GMERS, Sola, Ahmedabad. Int J Pharm Bio-Sci. 2015;2(1)

24. Gielchinsky Y, Rojansky N, Fasouliotis SJ, Ezra Y. Placenta accreta-summary of 10 years: a survey of 310 cases. Placenta. 2002;23(2):210-4.

25. Nizam K, Haider G, Memon N, Haider A. Cesarean section rate: much room for reduction. Rawal Med J. 2010;35:19-22.
26. Nizam K, Haider G, Memon N, Haider A. Cesarean section rate: much room for reduction. Rawal Med J. 2010;35:19-22.

27. Chavda D, Goswam K, Dudhrejiya K. A cross sectional study of 1000 lower segment cesarean section in obstetrics and gynecology department of PD U Medical College, Rajkot, Gujarat, India. Int J Reprod Contracept Obstet Gynecol. 2017;6(4):118691.

Cite this article as: Chaurasia V, Shrivastava S. Record based analysis of indications and complications of 500 cases of lower segment cesarean sections at a tertiary care hospital. Int $\mathbf{J}$ Reprod Contracept Obstet Gynecol 2019;8:393-7. 